The Bangladesh Veterinarian (2012) 29(2) : 56 - 62

\title{
Comparison of genes as target for molecular diagnosis of peste des petits ruminants in goats
}

\author{
A. R. Bhuiyan, M. M. Rahman, J. A. Begum, M. R. Islam and E. H. Chowdhury* \\ Department of Pathology, Faculty of Veterinary Science, Bangladesh Agricultural \\ University, Mymensingh-2202, Bangladesh
}

\begin{abstract}
Peste des petits ruminants (PPR) are an acute viral disease of sheep and goats. Rapid and accurate diagnosis is essential for successful control. Reverse transcriptase polymerase chain reaction (RT-PCR), a molecular diagnostic test based on amplification of the gene target is more sensitive than other tests. The study was to find an efficient primer set and structural gene, which would be more specific and sensitive for detecting PPR virus (PPRV) in field samples. Six primer sets for six structural genes of PPR were used. Primer against NP gene (np3/np4) was specific and sensitive. To ensure efficient amplification and detection of viruses in field samples, more than one set of primers should be used and F and N gene specific primers were the most suitable. (Bangl. vet. 2012. Vol. 29, No. 2, $56-62)$
\end{abstract}

\section{Introduction}

Peste des petits ruminants (PPR) is an acute viral disease of sheep and goats characterized by fever, catarrhal inflammation of ocular and nasal mucous membrane, erosive stomatitis, gastroenteritis and pneumonia. The causal agent is PPR virus (PPRV) an envelope, pleomorphic particle containing single-stranded RNA, approximately $16 \mathrm{~kb}$ long with negative polarity genome (Barrett et al., 2005). The genome of the virus codes for six structural $(N, P, M, F, H$ and $L)$ and two nonstructural $\left(C\right.$ and $V$ ) proteins in the order of $3^{\prime}-N-P(C / V)-M-F-H-L-5^{\prime}$ (Bailey et al., 2005, Mahapatra et al., 2006). The disease is prevalent in most African and Middle Eastern countries and the Indian subcontinent (Taylor, 1984). Morbidity and mortality of the disease can be as high as 100\% and 90\%, respectively (Abu-Elzein et al., 1990, Dhar et al., 2002). In Bangladesh, outbreaks of PPR were first reported in 1993 (Sil et al., 1995; Islam et al., 2001). Since then the disease has caused severe losses and is presently considered one of the major threats to about 22 million small ruminants in Bangladesh where mortality may reach $100 \%$. At present, more than 1 billion sheep and goats in Africa and Asia are at risk of PPR (EMPRES, 2009). Rapid diagnosis is essential for successful control. Reverse transcriptase polymerase chain reaction (RTPCR), a molecular diagnostic test based on amplification of the gene target offers a new strategy for diagnosis of PPRV, and is more sensitive than other tests. RT-PCR also offers the possibility of analysing the relationship between

${ }^{*}$ Corresponding author:- E-mail: emdad001@yahoo.com 
different PPRV strains for epidemiological studies (Shaila et al., 1996; Ozkul et al., 2002; Kwiatek et al., 2007; Wang et al., 2009; Balamurgan et al., 2010). Although RTPCR overcomes the limitations of conventional tests, the sensitivity varies depending on the primer used and the gene targeted. This may be due to high rate of nucleotide substitution error in RNA viruses (Steinhauer and Holland, 1986). The present study was undertaken to find an efficient primer set and gene, which would be specific and sensitive for detecting PPRV in field samples.

\section{Materials and Methods}

Samples

A total of 10 field samples were collected from dead PPR suspects. Mesenteric and bronchial lymph nodes and lung tissues were collected in sterile Falcon tubes. Pooled tissues were macerated using PBS as $20 \%(\mathrm{w} / \mathrm{v})$ suspension, centrifuged at $800 \mathrm{~g}$ for 10 minutes. The supernatant was collected in fresh sterile Falcon tubes, gentamycin was added $500 \mu \mathrm{g} / \mathrm{mL}$ and stored at $-20^{\circ} \mathrm{C}$. Freeze-dried live PPR vaccine from Livestock Research Institute (LRI), Department of Livestock Services and a previously identified isolate were used as the positive controls. When needed RNA was extracted from the same homogenate.

PCR

RNA was isolated from the tissue suspension and vaccine virus using RNeasy Kit (Qiagen, Germany) as recommended by the manufacturer. Initially standardized RTPCR specific for F and N genes were used individually to detect PPRV from each suspect. Samples found positive with $\mathrm{F}$ and $\mathrm{N}$ gene specific primers were used for further RT-PCR using P, M, H and L gene specific primers (Table 1). In all cases the reaction was set up as 5xQiagen One Step RT-PCR buffer $5 \mu \mathrm{L}$, dNTP Mix (containing $10 \mathrm{mM}$ of each dNTP) $1 \mu \mathrm{L}$, Primer forward $(100 \mathrm{pmol} / \mu \mathrm{L}) 0.5 \mu \mathrm{L}$, Primer reverse $(100 \mathrm{pmol} / \mu \mathrm{L}) 0.5 \mu \mathrm{L}$, Qiagen One Step RT-PCR Enzyme Mix $1.0 \mu \mathrm{L}$, template RNA $5 \mu \mathrm{L}$, total reaction volume $25 \mu \mathrm{L}$. First the RNA was reverse transcribed by incubating at $50^{\circ} \mathrm{C}$ for 30 minutes, then the PCR started with an initial denaturation and activation of Taq polymerase at $95^{\circ} \mathrm{C}$ for 15 minutes. Annealing, elongation and final extension steps were standardized: Table 2 shows standardized temperature and time profile used. The expected band was visualized in $1.5 \%$ agarose gel stained with ethidium bromide. The result was viewed on the monitor; the image was printed and saved electronically.

\section{Determination of sensitivity of primer}

RT-PCR was done further using diluted RNA and primer(s) that detected PPR virus in more field samples. Extracted RNA was quantified, and 10-fold dilution was made (Undiluted, $10^{-1}, 10^{-2}, 10^{-3}, 10^{-4}, 10^{-5}$ ). One step RT-PCR was performed for each dilution. Judgment was made after electrophoresis on 1.5\% agarose. The highest dilution that failed to amplify was considered as detection limit. Primers that 
successfully amplified at highest dilution without background reaction were considered more sensitive.

Table 1. PCR primers used, sequences and specificity

\begin{tabular}{|c|c|c|c|c|c|}
\hline Specificity & Primer name & Sequence & Position & Size & References \\
\hline \multirow{2}{*}{ F gene } & PPRV F1b & $\begin{array}{l}\text { 5'AGTACAAAAGATTGCTGATC } \\
\text { ACAGT-3' }\end{array}$ & $760-784$ & \multirow[t]{2}{*}{$448 \mathrm{bp}$} & \multirow[t]{2}{*}{ Ozkul, 2002} \\
\hline & PPRV F2d & $\begin{array}{l}\text { 5’-GGGTCTCGAAGGCTAGGCCC } \\
\text { GAATA- 3' }\end{array}$ & $1207-1183$ & & \\
\hline \multirow[t]{2}{*}{$\mathrm{N}$ gene } & NP3 & $\begin{array}{l}\text { 5'-TCTCGGAAATCGCCTCACAG } \\
\text { ACTG -3' }\end{array}$ & $1232-1255$ & \multirow[t]{2}{*}{$351 \mathrm{bp}$} & \multirow[t]{2}{*}{$\begin{array}{c}\text { Couacy- } \\
\text { Hymann et al., } \\
2002\end{array}$} \\
\hline & NP4 & $\begin{array}{l}\text { 5'-CCTCCTCCTGGTCCTCCAGA } \\
\text { ATCT -3' }\end{array}$ & 1583 & & \\
\hline \multirow{2}{*}{ L gene } & pprl for2 & $\begin{array}{l}\text { 5'-TGGAGCATTGTGGCATTGAC } \\
\text { AC-3' }\end{array}$ & $971-993$ & \multirow[t]{2}{*}{$804 b p$} & \multirow[t]{2}{*}{$\begin{array}{l}\text { Muthuchelvan, } \\
2005\end{array}$} \\
\hline & pprl rev2 & $\begin{array}{l}\text { 5'-GTCATGCTCGTCTTTTGCCAT } \\
\text { C-3' }^{\prime}\end{array}$ & 1774-1753 & & \\
\hline \multirow[t]{2}{*}{ M gene } & ppr_mfor1 & $\begin{array}{l}\text { 5'-AGGAGCAAGGGCAACTGAG } \\
\text { C-3' }\end{array}$ & $1-20$ & \multirow[t]{2}{*}{$780 \mathrm{bp}$} & \multirow[t]{2}{*}{$\begin{array}{l}\text { Muthuchelvan, } \\
2006\end{array}$} \\
\hline & rev2 & 5'AGGCAAAAACTAGACCCATC-3' & $780-761$ & & \\
\hline \multirow[t]{2}{*}{ P gene } & pprp_for1 & $\begin{array}{l}\text { 5'-TAGGACCCAGGTCAAGCAA } \\
\text { C-3' }\end{array}$ & $03-22$ & \multirow[t]{2}{*}{767 bp } & \multirow[t]{2}{*}{$\begin{array}{l}\text { Muthuchelvan, } \\
\text { et al., } 2006\end{array}$} \\
\hline & pprp_rev2 & 5'-GACTGAGTTCCCGTCTGTGC-3' & $769-750$ & & \\
\hline \multirow[t]{2}{*}{ H gene } & Pprh_fr1 & 5’-TGTCATGTTCTTATAGAGTT-3’’ & $1500-1519$ & \multirow[t]{2}{*}{$328 \mathrm{bp}$} & \multirow[t]{2}{*}{$\begin{array}{l}\text { Balamurgan } \\
\text { et al., } 2006\end{array}$} \\
\hline & Pprh_re2 & 5'-GACTGGATTACATGTTACCT-3' & $1847-1828$ & & \\
\hline
\end{tabular}

Table 2. PCR conditions for different primer sets used

\begin{tabular}{|c|c|c|c|c|c|c|c|c|}
\hline \multirow[t]{2}{*}{ Gene } & \multirow[t]{2}{*}{ Primer pair } & \multicolumn{6}{|c|}{ PCR condition (s) at program step } & \multirow{2}{*}{$\begin{array}{c}\text { Expected } \\
\text { target size }\end{array}$} \\
\hline & & 1 & 2 & 3 & 4 & 5 & 6 & \\
\hline \multirow[t]{2}{*}{ F gene } & PPRV F1b & $95^{\circ} \mathrm{C}$ & $94^{\circ} \mathrm{C}$ & $50^{\circ} \mathrm{C}$ & $72^{\circ} \mathrm{C}$ & \multirow{2}{*}{$\begin{array}{l}35 \text { cycles from } \\
\text { step } 2 \text { to } 4\end{array}$} & $72^{\circ} \mathrm{C}$ & \multirow[t]{2}{*}{448 bp } \\
\hline & PPRVF2d & $15 \mathrm{~min}$ & $1 \mathrm{~min}$ & $1 \mathrm{~min}$ & $2 \mathrm{~min}$ & & $7 \mathrm{~min}$ & \\
\hline \multirow[t]{2}{*}{$\mathrm{N}$ gene } & NP3 & $95^{\circ} \mathrm{C}$ & $94^{\circ} \mathrm{C}$ & $55^{\circ} \mathrm{C}$ & $72^{\circ} \mathrm{C}$ & \multirow{2}{*}{$\begin{array}{l}35 \text { cycles from } \\
\text { step } 2 \text { to } 4\end{array}$} & $72^{\circ} \mathrm{C}$ & \multirow[t]{2}{*}{$351 \mathrm{bp}$} \\
\hline & NP4 & $15 \mathrm{~min}$ & $30 \mathrm{~s}$ & $30 \mathrm{~s}$ & $30 \mathrm{~s}$ & & $10 \mathrm{~min}$ & \\
\hline \multirow[t]{2}{*}{ L gene } & pprl for2 & $95^{\circ} \mathrm{C}$ & $95^{\circ} \mathrm{C}$ & $50^{\circ} \mathrm{C}$ & $72^{\circ} \mathrm{C}$ & \multirow{2}{*}{$\begin{array}{l}30 \text { cycles from } \\
\text { step } 2 \text { to } 4\end{array}$} & $72^{\circ} \mathrm{C}$ & \multirow[t]{2}{*}{804 bp } \\
\hline & pprl rev2 & $15 \mathrm{~min}$ & $1 \mathrm{~min}$ & $1 \mathrm{~min}$ & $2 \min$ & & $10 \mathrm{~min}$ & \\
\hline \multirow[t]{2}{*}{ M gene } & ppr_mfor1 & $95^{\circ} \mathrm{C}$ & $95^{\circ} \mathrm{C}$ & $50^{\circ} \mathrm{C}$ & $72^{\circ} \mathrm{C}$ & \multirow{2}{*}{$\begin{array}{c}30 \text { cycles from } \\
\text { step } 2 \text { to } 4\end{array}$} & $72^{\circ} \mathrm{C}$ & \multirow[t]{2}{*}{780 bp } \\
\hline & ppr_mrev2 & $15 \mathrm{~min}$ & $1 \mathrm{~min}$ & $1 \mathrm{~min}$ & $2 \mathrm{~min}$ & & $10 \mathrm{~min}$ & \\
\hline \multirow[t]{2}{*}{ P gene } & pprp_for1 & $95^{\circ} \mathrm{C}$ & $95^{\circ} \mathrm{C}$ & $50^{\circ} \mathrm{C}$ & $72^{\circ} \mathrm{C}$ & \multirow{2}{*}{$\begin{array}{l}30 \text { cycles from } \\
\text { step } 2 \text { to } 4\end{array}$} & $72^{\circ} \mathrm{C}$ & \multirow[t]{2}{*}{$767 \mathrm{bp}$} \\
\hline & pprp_rev2 & $15 \mathrm{~min}$ & $1 \mathrm{~min}$ & $1 \mathrm{~min}$ & $2 \mathrm{~min}$ & & $7 \mathrm{~min}$ & \\
\hline \multirow{2}{*}{ H gene } & Pprh_fr1 & $95^{\circ} \mathrm{C}$ & $94^{\circ} \mathrm{C}$ & $55^{\circ} \mathrm{C}$ & $72^{\circ} \mathrm{C}$ & \multirow{2}{*}{$\begin{array}{c}29 \text { cycles from } \\
\text { step } 2 \text { to } 4\end{array}$} & $72^{\circ} \mathrm{C}$ & \multirow[t]{2}{*}{347 bp } \\
\hline & Pprh_re2 & $15 \mathrm{~min}$ & $30 \mathrm{~s}$ & $30 \mathrm{~s}$ & $30 \mathrm{~s}$ & & $7 \mathrm{~min}$ & \\
\hline
\end{tabular}

\section{Results and Discussion}

Out of ten field samples, seven tested positive with one or more primers and three were negative with all primers (Figs. 1 - 6). The results showed that $\mathrm{F}$ gene specific 
primer could detect six samples out of ten but gave non-specific band with some samples (Fig. 1). N gene specific primers detected PPRV in seven samples, with no non- specific bands (Fig. 2). The same six samples were positive in both cases. The 7 th sample was positive with $\mathrm{N}$ specific primers but negative with $\mathrm{F}$. The primers specific for L, M and P gene did not consistently detect PPRV (Figs. 3 - 5) and the primers specific for $\mathrm{H}$ gene failed to detect PPRV in any sample (Fig. 6). Dhar et al. (2002) noted that F1/F2 primer set did not work efficiently on a few samples. Three samples negative in conventional $\mathrm{F}$ gene based PCR were found positive by primers specific for $\mathrm{N}$ gene (Kerur et al., 2008). None of the samples positive in F gene based PCR was negative by the two $\mathrm{N}$ gene based primers. $\mathrm{N}$ gene based primers were more sensitive than $\mathrm{F}$ gene based primers (Kerur et al., 2008). The lower sensitivity with $\mathrm{F}$ gene specific primers might be attributed to nature of PPRV genome which shows higher rate of transcription of N-gene than F-gene. The target for PCR primers developed by Forsyth and Barrett (1995) was F gene, one of the external viral proteins. The $\mathrm{N}$ gene codes for an internal structural protein and mRNAs of $\mathrm{N}$ gene are the most abundant transcripts of the virus, making it attractive for development of a highly sensitive assay (Steinhauer and Holland, 1986).

In the present experiment, one isolate could not be amplified with $\mathrm{F}$ gene specific primer pair (F1b-F2d). This could be primer-template mismatch in the annealing site or low sensitivity of the test protocol. In the absence of sequence information conclusive inference could not be drawn on a possible mutation in the primer binding site. Failure of the other primers sets to detect PPRV in the field samples consistently could not be readily explained. RNA viruses are known to contain high rate of nucleotide substitution error (Steinhauer and Holland, 1986). To ensure efficient amplification and detection of PPR viruses, it is desirable to have more than one set of primers for diagnosis, and $\mathrm{F}$ and $\mathrm{N}$ genes are the most suitable (Kerur et al., 2008). $\mathrm{F}$ and $\mathrm{N}$ specific primers could detect PPRV clearly until dilution 10-2 $(7.5 \mathrm{ng} / \mu \mathrm{L})$ (Fig. 7 -8). Although F gene specific primer could detect at higher dilution (10-5 or 7.5 $\mathrm{pg} / \mu \mathrm{L}$ ) a strong non-specific band began to appear simultaneously at dilution 10-3 and above (Fig. 7), which could not be readily explained. No such non-specific amplification was noticed with $\mathrm{N}$ gene specific primer (Fig. 8).

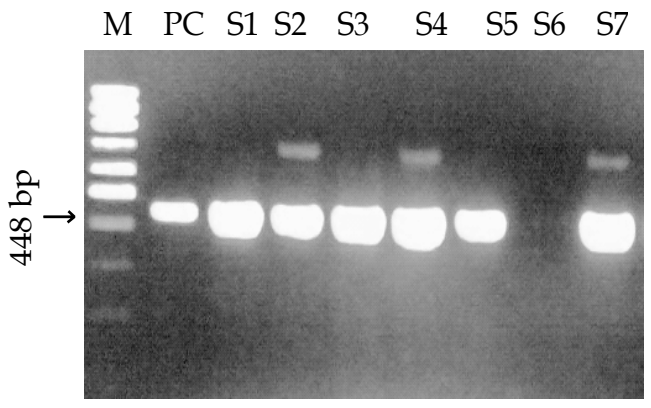

Fig. 1. Amplification of the fragment of F gene using specific Primer with different field samples
M NC S1 S2 S3 S4 S5 S6 S7 PC

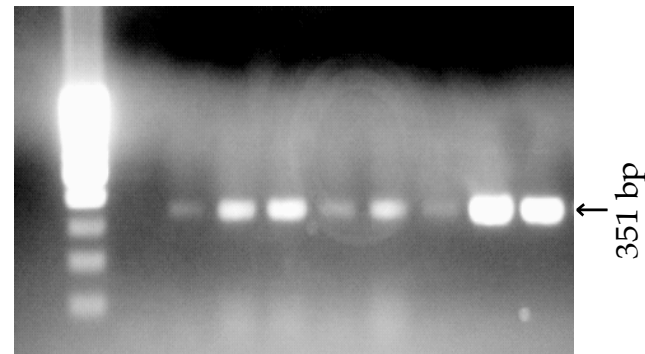

Fig. 2. Amplification of the fragment of $\mathrm{N}$ gene using specific Primer with different field samples 


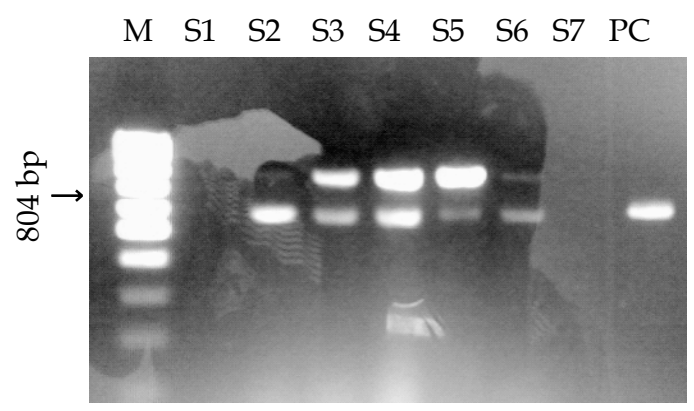

Fig. 3. Amplification of the fragment of L gene using specific primer with different field samples

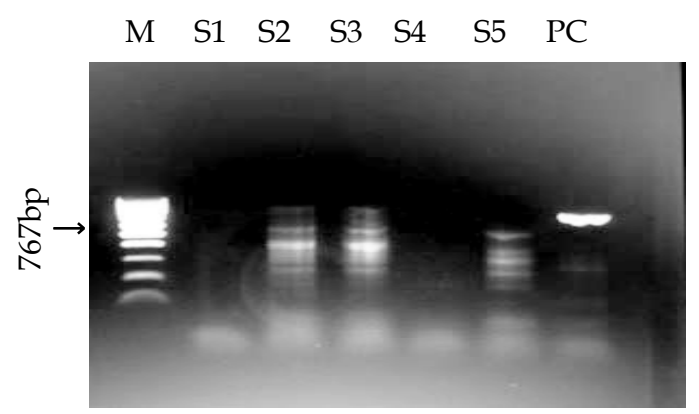

Fig. 5. Amplification of the fragment of P gene using specific primer with different field samples

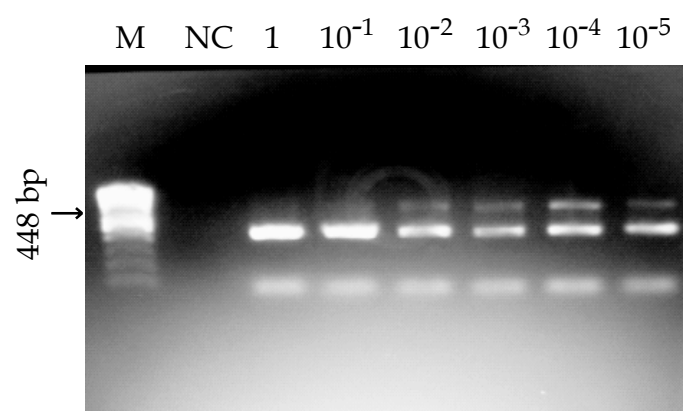

Fig. 7. RT-PCR with $\mathrm{F}$ gene specific primer at different dilution, Conc. of RNA : $1=750$ $\mathrm{ng} / \mu \mathrm{L}, 10^{-1}=75 \mathrm{ng} / \mu \mathrm{L}, 10^{-2}=7.5 \mathrm{ng} / \mu \mathrm{L}$

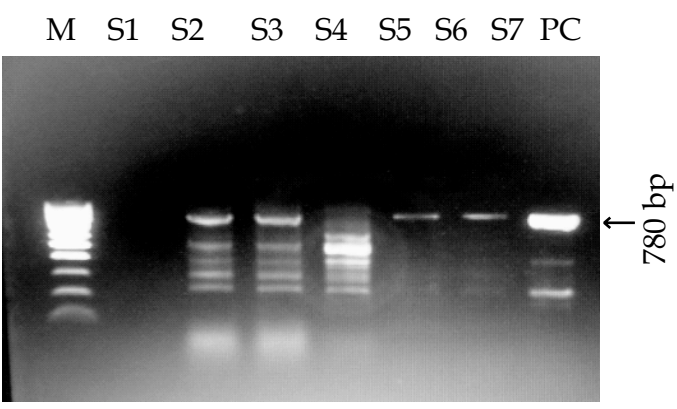

Fig. 4. Amplification of the fragment of $\mathrm{M}$ gene using specific primer with different field samples

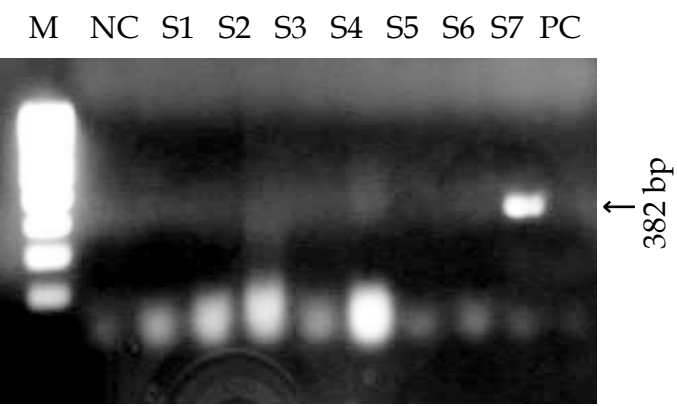

Fig. 6. Amplification of the fragment of $\mathrm{H}$ gene using specific primer with different field samples

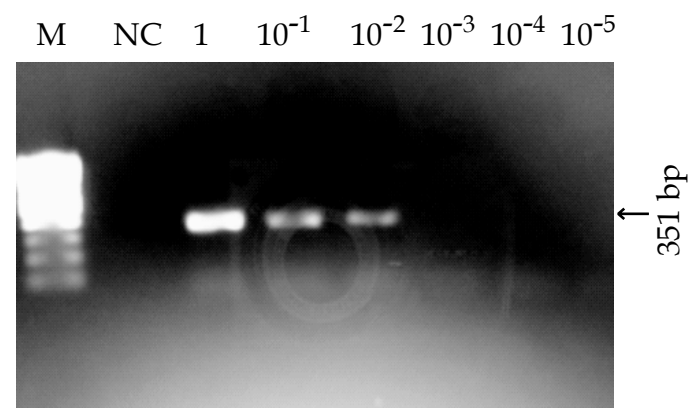

Fig. 8. RT-PCR with $\mathrm{N}$ gene specific primer at different dilution, Conc. of RNA : $1=750$ $\mathrm{ng} / \mu \mathrm{L}, 10^{-1}=75 \mathrm{ng} / \mu \mathrm{L}, 10^{-2}=7.5 \mathrm{ng} / \mu \mathrm{L}$

\section{Conclusions}

Primer against NP gene (np3/np4) was specific and sensitive for the detection of PPRV from field samples but for efficient amplification and detection of viruses in field samples, it is desirable to have more than one set of primers for diagnosis; and $\mathrm{F}$ and $\mathrm{N}$ genes are the most suitable. 


\section{Acknowledgements}

We thank IAEA, Vienna, Austria and PIU, BARC, Dhaka for funds and facilities

\section{References}

AbuElzein EME, Hassanien MM, AlfaleQ AIA, Elhadi MMA, Housawi FMT 1990: Isolation of PPR virus from goats in Saudi Arabia. Veterinary Reccord 127 309-310.

Bailey D, Banyard A, Dash P, Ozkul A, Barrett T 2005: Full genome sequence of Peste des petits ruminants virus, a member of the Morbillivirus genus. Virus Research $\mathbf{1 1 0}$ 119-124.

Balamurgan V, Sen A,Venkatesan G, Ydav V, Bhanot V, Ryyesh T, Bhanuprakash V, Singh RK 2010: Sequence and Phylogenetic Analysis of the Structural genes of Virulent Isolates and Vaccine Strains of Peste des petits ruminants Virus from India. Transboundary and Emerging Diseases 57 352-364.

Barrett T, Banyard AC, Diallo A 2005: Molecular Biology of the Morbilliviruses Virus plagues of large and small ruminants. Elsevier, Amsterdam, the Netherlands, pp: 31-67.

Couacy-Hymann E, Roger F, Hurard C, Guillou JP, Libeau G, Diallo A 2002: Rapid and sensitive detection of Peste des petits ruminants virus by a polymerase chain reaction assay. Journal of Virological Methods 100 17-25.

Dhar P, Sreenivasa BP, Barrett T, Corteyn M, Singh RP, Bandyopadhyay SK 2002: Recent epidemiology of peste des petits ruminants' virus (PPRV). Veterinary Microbiology $\mathbf{8 8}$ 153-159.

EMPRES, (Emergency Prevention System for Transboundary Animal and Plant Pests and Diseases) 2009: Recognizing peste des petits ruminants: a field manual. Rome, Italy: FAO (Food and Agriculture Organization of the United Nations).

Forsyth MA, Barrett T 1995: Evaluation of polymerase chain reaction for the detection and characterisation of rinderpest and Peste des petits ruminants viruses for epidemiological studies. Virus Research 39 151-63.

Islam MR, Shamsuddin M, Das PM, Dewan ML 2001: An outbreak of peste des petits ruminants in Black Bengal goats in Mymensingh, Bangladesh. The Bangladesh Veterinarian 18 14-19.

Kerur N, Jhala MK, Joshi CG 2008: Genetic characterization of Indian peste des petits ruminants virus (PPRV) by sequencing and phylogenetic analysis of fusion protein and nucleoprotein gene segments. Research in Veterinary Science 85 176-183.

Kwiatek O, Minet CG, Hurardy CC, Carlssonz E, Karimovz B, Albina E, Diallo A, Libeau G 2007: Peste des Petits Ruminants (PPR) Outbreak in Tajikistan. Journal of Comparative Pathology 136 111-119.

Mahapatra M, Parida,S, Baron MD, Barrett T 2006: Matrix protein and glycoproteins F and $\mathrm{H}$ of Peste-des-petits-ruminants virus function better as a homologous complex. Journal of General Virology 87 2021-2029. 
Muthuchelvan D, Sanyal A, Sreenivasa BP, Saravanan P, Dhar RP, Singh RK, Bandyopadhyay SK 2006: Analysis of the matrix protein gene sequence of the Asian lineage of peste des petits ruminants vaccine virus. Veterinary Microbiology 113 83-87.

Muthuchelvan D, Sanyal A, Singh RP, Hemadri D, Sen A, Sreenivasa BP, Singh RK, Bandyopadhyay SK 2005: Comparative sequence analysis of the large polymerase protein (L) gene of peste-des-petits ruminants (PPR) vaccine virus of Indian origin. Archive of Virology 150 2467-2481.

Ozkul A, Akca Y, Alkan F, Barrett T, Karaoglu T, Dagalp SB, Anderson J, Yesilbag K, Cokcaliskan C, Gencay A, Burgu I 2002: Prevalence, distribution, and host range of Peste des petits ruminants virus, Turkey. Emergence Infectious Diseases 8 708-712.

Shaila MS, Shamaki D, Forsyth MA, Diallo A, Goatley L, Kitching RP, Barrett T 1996: Geographic distribution and epidemiology of Peste des petits ruminants viruses. Virus Research 43 149-153.

Sil BK, Rahman MM, Taimur MJFA, Sarker AJ 1995: Observation of outbreaks of PPR in organized goat farms and its control strategy. Presented at the Annual Conference of the Bangladesh Society of Veterinary Education and Research, 3 December, BARC, Dhaka.

Steinhauer DA, Holland JJ 1986: Rapid evolution of RNA viruses. Annual Review of Microbiology 41 409-433.

Taylor WP 1984: The distribution and epidemiology of PPR. Preventive Veterinary Medicine 2 157-166

Wang Z, Bao J, Wu X, Liu U, Li L, Liu C, Suo L, Xie Z, Zhao W, Zhang W, Yang N, Li J, Wang S, Wang J 2009: Peste des Petits Ruminants Virus in Tibet, China. Emergence Infectious Diseases 15 299-301. 